\title{
Understanding about the classification of pulp inflammation
}

\author{
Trijoedani Widodo \\ Department of Conservative Dentistry \\ Faculty of Dentistry Airlangga University \\ Surabaya - Indonesia
}

\begin{abstract}
Since most authors use the reversible pulpitis and irreversible pulpitis classification, however, many dentists still do not implement these new classifications. Research was made using a descriptive method by proposing questionnaire to dentists from various dental clinics. The numbers of the dentists participating in this research are 22 dentists. All respondents use the diagnosis sheet during their examinations on patients. Nonetheless, it can't be known what diagnosis card used and most of the dentists are still using the old classification. Concerning responses given towards the new classification: a) the new classification had been heard, however, it was not clear (36.3\%); b) the new classification has never been heard at all (63.6\%). Then, responses concerning whether a new development is important to be followed-up or not: a) there are those who think that information concerning new development is very important (27.2\%); $b$ ) those who feel that it is important to have new information $(68.3 \%)$; c) those who think that new information is not important (8\%). It concluded that information concerning the development of classification of pulp inflammation did not reach the dentists.
\end{abstract}

Key words: Classification, Reversible pulpitis, Irreversible pulpitis

Correspondence: Trojoedani Widodo, c/o: Bagian Konservasi Gigi, Fakultas Kedokteran Gigi Universitas Airlangga. Jln. Mayjend. Prof. Dr. Moestopo 47 Surabaya 60132, Indonesia.

\section{INTRODUCTION}

The classification of a type of diseases is really needed to decide the treatment indication easily. The classification is also important for pulp disease, nonetheless, the exactly classification of pulp inflammation or pulpitis has never been found. ${ }^{1}$ It is mentioned that a challenge faced by dentists in classifying right on pulp diseases is due to the other symptoms often accompanying especially during the transitional period of the pulp diseases. In dentists' office or in the dental clinics, the dentist use various classification of pulp inflammation and indication of treatment.

Previously some classifications have already been made, those were classifications made by Bence ${ }^{2}$ and Knap ${ }^{3}$ at 1976, Grossman $^{4}$ at 1981, and Shafer et al. ${ }^{5}$ at 1983. Smulson $^{6}$ at 1984 stated that it is very important to assume the inflammation level happened in order to classify the pulp inflammation. We should distinguish the pulp tissues condition that could be kept under pulp capping treatment and the pulp tissues that need pulpectomy because it could not be maintained anymore. He classified the pulpitis into reversible pulpitis and irreversible pulpitis. Reversible pulpitis is mild to medium pulp inflammation caused by stimulation and the defense system of the pulp tissue is still able to recover. While irreversible pulpitis is severe pulp inflammation caused by a type of stimulation and the defense system of the pulp tissue cannot overcome it longer, and this cannot be recovered or healed. Other authors followed up this classification later on, for examples:
Grossman et al. ${ }^{7}$ at $1988 ;$ Wiene $^{8}$ at 1989 ; Simon et al. ${ }^{9}$ at 1994; Walton and Torabinejad ${ }^{10}$ at 1996; Mount and Hume $^{11}$ at 1998 , Beer et al. ${ }^{12}$ at 2000, Stock et al. ${ }^{13}$ and Pitt Ford $^{14}$ at 2004 . Widodo ${ }^{15}$ at 1997 in her research classified the pulpitis into reversible pulpitis and irreversible pulpitis to express the immunopathological change happened in the pulp inflammation using immunopatological concept and morfofunctional on inflammation of pulp tissues.

Most authors using the reversible pulpitis and irreversible pulpitis classification, however, many dentists still do not implement these new classifications. Based on this phenomena, there is a problem about is there a difference to determine the diagnosis of pulp inflammation and why the new classification is not been adopted by dentists in clinics.

Therefore, a research was made using a descriptive research method, ${ }^{16}$ by proposing questionnaires to dentists from various dental clinics covering: dental clinics in government hospitals, dental clinics in private hospitals, dental clinics in government hospitals in public health centers, and laboratory clinics in the area of Faculty of Dentistry Airlangga University. Then an analysis was made on the collected questionnaires, to know whether there was any change in the diagnostic techniques implemented to find the pulpitis classification, and some responses over the new classification. It is through this practice that the cause of not using the new classification method is found and how the effort should be made to get the same understanding about the pulpitis classification. 


\section{MATERIAL AND METHOD}

The purpose of this research is to find an explanation concerning an objective situation, how the dentists-inclinics diagnosed in determining the classification of a disease and its treatment plan implemented. The data is collected from the dentists, and the method used in this research is descriptive research method. ${ }^{16}$

The population of this research were the dentists. Some of the samples were the dentists at Surabaya, working at the dental clinics in private hospitals, government hospitals, dental clinics in government hospitals in public health centers, and laboratory clinics in the area of Faculty of Dentistry Airlangga University. While the analysis unit is the answer given through the questionaires.

The questionnaires sheet is used as a supporting instrument for data collection. The questionnaires were distributed among the 22 dentists, consist of two dentists from two dental laboratories in the area of Faculty of Dentistry, Airlangga University, two dentists from the public health center at Surabaya, some dentists of the private hospital at Surabaya, and some dentists who are participating a training in the Hospital of Dr. Soetomo, Surabaya. The questionnaires sheets were presented by giving some explanations that it will not go far beyond the expectation of the researchers.

A descriptive analysis was made upon the collected data. The diagnosis performed to understanding concerning classification of pulp inflammation, their knowledge about the development of new classification; reversible pulpitis and irreversible pulpitis. Moreover, it was also observed their responses towards the current development of dental sciences especially dental conservation.

\section{RESULT}

The number of the dentists participating in this research is 22. They consisted of two dentists from dental laboratory in the area of Faculty of Dentistry, Airlangga University, two dentists from the public health center at Surabaya, five dentists of the private hospital at Surabaya, two dentists from Navy Department i.e., from the dental laboratory of Navy (LADOKGI YOS SUDARSO) in Ujung Pandang, dentist of the dental clinic of the Hospital of Tk.III Kasdam V Brawijaya Surabaya, and ten dentists coming from various hospitals participating a training in Dr. Sutomo Hospital. The result of the questionnaire can be seen as shown in Table 1.

The questionnaire proposed to the dentists is accompanied by giving some explanations about how to fill the forms. All respondents use the diagnosis sheet during their examinations on patients as seen in Table 1. Nonetheless, it cannot be known the diagnosis card that the dentists used and most of the dentists were used old classification. Concerning responses given towards the new classification: a) the new classification has ever been heard, but not clearly, responded by eight (8) dentists $(36.3 \%)$; b) the new classification has never been heard at all, responded by fourteen (14) dentists (63.6\%). The response of the dentists about whether a new development is important to be followed-up or not: a) the information about new development is very important, was responded by six dentists (27.2\%); b) those who feel that it is important to have new information was responsed by fifteen dentists $(68.3 \%)$; c) those who think that new information is not important was responded only by one person $(8 \%)$.

\section{DISCUSSION}

The purpose of this research is to examine the understanding of classification of pulp inflammation among the dentists. The data obtained through the questionnaires and this research was the descriptive research. The dentists involved in the research were the dentists who live in Surabaya, both as permanent residents or as graduate students who are studying in Surabaya. It is expected that the information collected was more widespread and varies. Each institution has their own standards, demands, or regulations to determine the diagnosis of a disease related to the classification of the disease. The classification is

Table 1. The result of questionnaire from 22 dentists about diagnostic techniques, classification reversible pulpitis and irreversible pulpitis

\begin{tabular}{|c|c|c|c|c|}
\hline & $\begin{array}{l}\text { Diagnostic } \\
\text { Techniques }\end{array}$ & $\begin{array}{c}\text { Using } \\
\text { Classification }\end{array}$ & $\begin{array}{c}\text { Given toward } \\
\text { new Classification }\end{array}$ & $\begin{array}{l}\text { Need new } \\
\text { information }\end{array}$ \\
\hline Using the Diagnostic Card & $22(100 \%)$ & & & \\
\hline Not Using the Diagnostic Card & 0 & & & \\
\hline Using old classification & & $22(100 \%)$ & & \\
\hline Using new classificatin & & 0 & & \\
\hline Has already known & & & 0 & \\
\hline Has ever heard but not very clear & & & $8(36.3 \%)$ & \\
\hline Has never heard at all & & & $14(63.3 \%)$ & \\
\hline Very Important & & & & $6(27.2 \%)$ \\
\hline Important & & & & $15(68.3 \%)$ \\
\hline Not important & & & & $1(8 \%)$ \\
\hline
\end{tabular}


important as the basic steps to determine any indication of treatment.

The dentists from two laboratories (Oral Surgery and Pedodontic) of Faculty of Dentistry, Airlangga University are chosen. In Oral Surgery laboratory, diagnosis of all the teeth are performed although extraction is the first priority, moreover, for the Pedodontic Laboratory, they perform diagnosis all of the teeth in detail. Some data were also collected from the dentists from the Private Hospital at Surabaya and the district hospital from various places, who are training in the Hospital of Dr. Soetomo. By doing this, a better understanding can be obtained. The purposes of the research are to observe whether classification of pulpitis is well understood, to know whether there is any difference in the diagnostic techniques, and determine the factor causing the new classification of pulpitis is not implemented yet.

Concerning the diagnostic techniques implemented in the pulpitis, the dentists have already used the diagnostic card. However, this action does not guarantee that a good understanding concerning the pulpitis is alike. Therefore, it is important to socialize the diagnostic techniques and the use of right diagnostic sheet. The basics of right choise of diagnosis implemented in local clinics given during studying seriously affect the understanding of the dentists concerning the classification of the pulpitis. It can be concluded that, it is very important for the dentists continuously follow the new development or techniques in the science of dental clinics.

The classification of pulpitis has already developed year to year, moreover in the understanding of hyperemia. According to the old concept hyperemia was not a disease but a coincidence before inflammation. ${ }^{2,3,4}$ Hyperemia is signed by the vasodilatation of the blood cells, it is a preliminary phase of an inflammation process that Shafer et $a .^{5}$ at 1983 started to change hyperemia term into focal reversible pulpitis, then it was emphasized by Smulson ${ }^{6}$ at 1984 using new term the reversible pulpitis. Reversible pulpitis as a mild to medium inflammation caused by a stimulation and the defense system of the pulp tissue is still able to overcome it that it can also be recovered. While the irreversible pulpitis is a severe inflammation which can't overcome it, so, it can't be recovered. , $^{6}$

The classification of the pulpitis turned to the reversible pulpitis and the irreversible pulpitis finally followed up by the other authors like: Grossman et al. ${ }^{7}$ at 1988 , Weine ${ }^{8}$ at 1989; Simon et al. ${ }^{9}$ at 1994; Walton and Torabinejad ${ }^{10}$ at 1996; Mount and Hume ${ }^{11}$ at 1998, Beer et al. ${ }^{12}$ at 2000, Stock et al. ${ }^{13}$ and Pitt Ford at 2004. Although this new classification started to be used in conservative dentistry textbooks since 1984, most of the dentists still use the old classification, especially the use of hyperemia pulpae.
Actually, the good understanding concerning the hyperemia pulpae was not applicable and it is important to correct it by using the right term, the reversible pulpitis as it means that it can be cured for the defense system of the pulp tissue is still able to overcome it. It was said that focal reversible pulpitis is a science term for hyperemia pulpae. ${ }^{17}$

It concluded that information concerning the development of classification of pulp inflammation did not reach the dentists. However, some of them, especially the dentists who work in town or suburb, try to get a new information about conservative dentistry through seminars. There is only one dentist who expressed that knowing new development of pulpitis diagnosis is not important, the reason is that he has a lot of patients in his clinic and most of the patient prefer to pull the tooth out.

\section{REFERENCES}

1. Widodo T. Pulp inflammation classification and their treatment indication. Journal of Dentofasial, Dental Faculty Hasaanudin University, Makasar 2003; 256.

2. Bence R. Endodontik klinik. Soendoro EH, editor. Jakarta: Penerbit Universitas Indonesia; 1976. p. 1-14.

3. Knapp M. Klasifikasi penyakit pulpa. In: Gardjito K. Perawatan gigi dengan diagnosis pulpitis partialis. Majalah Kedokteran Gigi Surabaya 1976. IV;6.

4. Grossman LI. Endodontic practice. $8^{\text {th }}$ ed. Philadelphia: Lea and Febriger; 1981. p. 26-61.

5. Shafer WG, Hien MK, Levy BM. A text book of oral pathology. $4^{\text {th }}$ ed. Philadelphia: WB Saunders Co; 1983. p. 479-510.

6. Smulson MH. Classification and diagnosis of pulp pathosis. The Dent Clin of North Am 1984; 28:699.

7. Grossman LI, Oliet S, del Rio CE. Endodontic practice. $11^{\text {th }}$ ed. Philadelphia: Lea and Febriger; 1988. p. 36-49.

8. Weine FS. Endodontic therapy. $4^{\text {th }}$ ed. London: The CV Mosby Co; 1989. p. 74-153.

9. Simon JHS, Walton RE, Pashley DH, Dowden WE, Bakland LK. Pulpal Pathology, In: Ingle JI, Bakland LK, editors. Endodontics. $4^{\text {th }}$ ed. Philadelphia. 1994. p. 422-26.

10. Walton RE, Torabinejad M. Prinsip dan praktik ilmu endodonsi. Narlan Sumawinata, Winiati Sidharta, Bambang Nursasongko, editors. Jakarata: Penerbit Buku Kedokteran EGC; 1996. p. 40-68.

11. Mount GJ, Hume WR. Preservation and restoration of tooth structure. London: The CV Mosby; 1998. p. 37-44.

12. Beer R, Baumann MA, Kim S. Atlas of dental medicine, endodontology. New York: Thiemu Stuttgard; 2000. p. 1-16.

13. Stock C, Walker R, Gulabivala K. Endodontics. $3^{\text {rd }}$ ed. London: Eidenburg; 2004. p. 74.

14. Pitt Ford TR. Harty's, endodontics in clinical practice. $5^{\text {th }}$ ed. London: Eidenburg; 2004. p. 37-38.

15. Widodo T. Analisis perubahan imunopatologik pada pulpitis reversibel dan ireversibel untuk memperbaiki diagnosis atas dasar imunopatogenesis pulpitis. Dissertation Surabaya: Universitas Airlangga; 1997.

16. Notoatmodjo S. Metodologi penelitian kesehatan. Jakarta: Penerbit PT Rineka Cipta; 1993. p. 135-40.

17. Crowford WH. Oral Pathology, 2003. Available at: http://www.usc.edu/ hst/dental/opath/chapters08_main.html. Accessed February 9, 2007. 